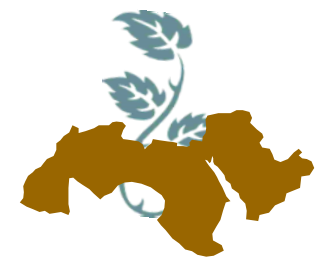

Arab Univ.

J. Agric. Sci., Ain Shams Univ., Cairo, 26(2), 539 - 547, 2018

\title{
FEED EFFICIENCY OF URBAN AND PERI-URBAN DAIRY PRODUCTION SYSTEMS
}

\author{
Elsrogi ${ }^{1}$, M.A.; M.A. El-Wardani ${ }^{1}$; H.M. Elsayed ${ }^{2}$ and M.M. Khorshed ${ }^{2}$ \\ [41] \\ 1- Animal Production Research Institute. Agric. Research Center. Ministry of Agric. , Dokki, Gi- \\ za, Egypt \\ 2- Animal Production Dept. Fac. of Agric., Ain Shams Univ., Cairo, Egypt.
}

Keywords: Urban, Peri-urban production systems, Dairy production systems, Feeding systems, Feed efficiency

\section{ABSTRACT}

The study aimed at estimating feed efficiency of milk production systems in Urban and Periurban areas in three main provinces in Egypt. The targeted provinces were: Cairo, Giza and Qaloubeya. A questionnaire has been developed to cover the variables related to the production systems. The total number of interviewers was 72 , included the districts: Manshiat Elbakary; Saft Elaban and Shalaquan as peri-urban, and Elmarg; Elomrania and Dar Elsalam as urban areas. As a result of the great significant in the selected samples, a typology has processed gathering similarities in two main groups of producers: land-access and landless producers. Three crop-livestock systems have been classified due to the concepts: land capacity and herd size (group 1,2 and 3). Dairy systems have been identified as two main urban dairy specialized systems (group 4 and 5) oriented to dairy activities. In order to measure feed efficiency for each system were represented in the groups, the most significant obtained results were: the small and the micro crop-livestock producers related land-access producers (group 2 and 3) which have small herd appear to be more efficient in valorizing feed in relation to milk production per head per year, and as well as milk production per feddan allocated to fodder crops. On contrary, the landless producers (group 4 and 5) have the lowest feed efficiency due to the amount of concentrates included in their feed strategy (intensive feeding system) and inability to produce fodders.
The large mixed crop-livestock system (group 1) represents an intermediate status that producers cultivate fodders inside farm, but remain low economic efficiency in terms of their intensive feed strategy. The results of the study indicated that the small and the micro crop-livestock (group 2 and 3) achieved the highest feed efficiency regarding milk production in Urban and Peri-urban areas and thus the importance of improving productive performance by creating supposed scenarios or technical packages using simulation systems. Nongovernmental organizations (NGOs) and extension programs are essential in performing records and marketing which help to raise product price as well as producers' income and the Gross Domestic Products (GDP).

\section{INTRODUCTION}

Systems theory and systems thinking suppose to give a general identification of understanding the communication of complex phenomena and components of systems (Sere and Steinfeld, 1996). Such an approach used to characterize the system-identifying inputs, outputs, potentials and constraints. The approach may involve designing interventions and elaborating on alternatives that have proven to be technically practical, economically feasible and socially acceptable (Le Moigene, 1977). Therefore, systems approach is essential to develop and implement research strategies.

Dairy production systems in Egypt classified under two main systems: mixed crop-livestock and commercial production systems. The mixed croplivestock systems are the major livestock production systems in the Nile Basin representing over 
$70 \%$ of all large ruminant population (buffalo and cattle), and around $80 \%$ of the total milk production. The commercial production systems can be represented in two sub-systems: intensive dairy farming system and peri-urban milk production system, in which milk production contributes only $20 \%$ of the total milk production (Tabana, 2000).

Urban and peri-urban areas describe the community based-agricultural according to proactive forms such as subsistence by individuals within themselves and with their families. Urban and periurban production systems refer changing in production density due to land prices which make these production systems more intensive, thus crop and animal production towards more perishable (Smith and Baikey, 2006). On Egypt context, few studies were conducted on urban and periurban production systems due to limitation of quantifiable information, especially for those social and environmental upon hard conditions surrounding when survey. In a study of Giza governorate, Abdel-Rehim (2005) reported that milk production is the major output of urban buffalo milk production systems, contributed $40 \%$ sold directly to consumer, while $60 \%$ is sold to middlemen. Average of total milk yield was $1699 \mathrm{~kg}$ in 211 lactating days with an average daily milk yield $8.1 \mathrm{~kg}$. Feeding costs represented as major variable costs (> 90\% of the total variable costs), where milk revenue was the most important output (80\%). Classification of urban and peri-urban dairy production systems is difficult and hard to give a valid definition that increasing demand doesn't lead to dairy sector structuration (Geleti et al 2014).

Efficiency is considered the main issue when determine the production systems appropriated for local conditions as well as to improve performance of such production systems. It can be focused on feed as a production process which maintains an optimized ratio both to reach an economical and technical efficiency knowing that feed represents the large amount of the total milk production cost (Bach, 2012). Therefore, the main variable can be distinguished to estimate the farming systems efficiency is milk production (Bach, 2012).

This study aims to analyzing feeding systems and their influences on milk production systems in urban and peri-urban areas located around the Greater Cairo by integrating technical and economic parameters throughout the assessment of production systems efficiency.

\section{MATERIALS AND METHODS}

\section{Questionnaire}

The questionnaire was created in 45 variables to investigate the following main topics: family composition; land and crop production; herd structure (animal composition and animal sale and purchase); feeding systems through summer and winter seasons and representation of main constants and farmer's future activities. The questionnaire was tested and modified after the first test round with 9 producers.

GPS-point was collected for each interview by using "snowball" sampling method.

\section{Sampling}

Within three months, 72 interviews were conducted. The areas which targeted for the survey were: Manshiat Elbakary (Giza); Saft Elaban (Giza) and Shalaquan (Qalioubeya) represented as periurban, and Elmarg (Cairo); Elomrania (Giza) and Dar Elsalam (Cairo) represented as urban areas (Fig. 1). Targeted areas were detected according to the distance from center Cairo. Twelve breeders were interviewed for each of those areas showing decline in number of breeders because of urban sprawl or high production costs. Moreover, there was difficulty in discussing certain matters relating economic and social status for some producers especially in the urban areas which led to shortages in some required data.

The "snowball sampling" technique (Goodman, 1960) was used for finding the producers in such targeted areas. This technique of sampling is mostly used for exploratory investigation or "hidden population". The technique is based on the relation between subjects who will guide to the next.

\section{Typology}

Typology process was conducted to classify farming systems in groups with similarities to give a global understanding of those classified groups (Landais, 1996). Multiple-Factor analysis (MFA) was developed to determine the main factors that describe farming systems as qualitative records considering farm unit. The theme of family gathers the variables related to family farm workforce, family size and contribution of family members salary. 




Fig. 1. Targeted areas for field survey

The theme of land gathers the variables related to the total owned area, cultivated area and percentage of types of crops (fodder, cereal and cash crops) for each included group. The theme of livestock gathers the variables related to herd size as Tropical Livestock Unit (TLU), percentage of dairy animals in the total large ruminants and percentage of each type of dairy animals (Buffalo, Crossbred and Baladi cattle).

R and R-studio (2013): open-access software was developed for statistical and graphical analysis. Principally, the package "ade4" was used to perform factor analysis and hierarchical clustering.

\section{Studied traits}

Six milk production related-traits were performed as following:

$\mathrm{Y}$ 1: number of dairy large animal,

Y2: \% buffalo in the total dairy large animal,

Y3: \% local in the total dairy animal,

Y4: \% crossbred in the total dairy animal,

Y5: total milk production per dairy animal per year, and

Y6: total milk production/ fodder crops per year.

\section{Data analysis}

The software which has been used to interpret the data collected is Microsoft Office Access: database management system from Microsoft Office allowing management on large set of data. Thus the variables which have been created were based on raw data collected in field;

Least square method, using general linear model procedure, SAS program (SAS, 2000) was the software used in analyzing data. Duncan Multiple range test (Duncan, 1955) was created to detect significant difference among means. The fixedlinear model was created to analyze the effect of groups as following:

$$
Y_{i j}=\mu+a_{i}+e_{i j}
$$

Where:

$Y_{i j}$ is the observation of different studied traits. $\mu$ is the overall mean,

$a_{i}$ is the fixed effect of $i^{\text {th }}$ groups where, $i=1$, 2,3,4,5 (1= large mixed crop-livestock system, $2=$ small mixed crop-livestock system, $3=$ micro crop-livestock system, 4=large herder's milk production and $5=$ small herder's milk production).

$e_{i j}$ is a random effect associated with the individual observation and assumed to be $\operatorname{NID}\left(0, \sigma^{2} \mathbf{e}\right)$.

\section{Efficiency}

The concept efficiency refers the process of ratio between input and output. The process has to maximize output while keeping input stable or decreasing (Farell, 1957). Feed efficiency was mainly 
calculated by performing dry matter (DM) intake regarding average milk production per head per year and average milk production per feddan cultivated by fodder crops.

\section{RESULTS AND DISCUSSION}

\section{Typology approach}

With preforming hierarchical clustering of the distance in the factorial plan of each farm (conducted by Multiple Factor Analysis (MFA)), five groups of farming systems were identified. The studied groups can be divided into two main production systems: Land-access and landless producers. The land-access producers have been developed by three groups: large mixed croplivestock system (group 1); small mixed croplivestock system (group 2) and micro mixed croplivestock system (group 3). The landless producers have been scaled as: large herder's milk production (group 4) and small herder's milk production (group 5) (Fig. 2).

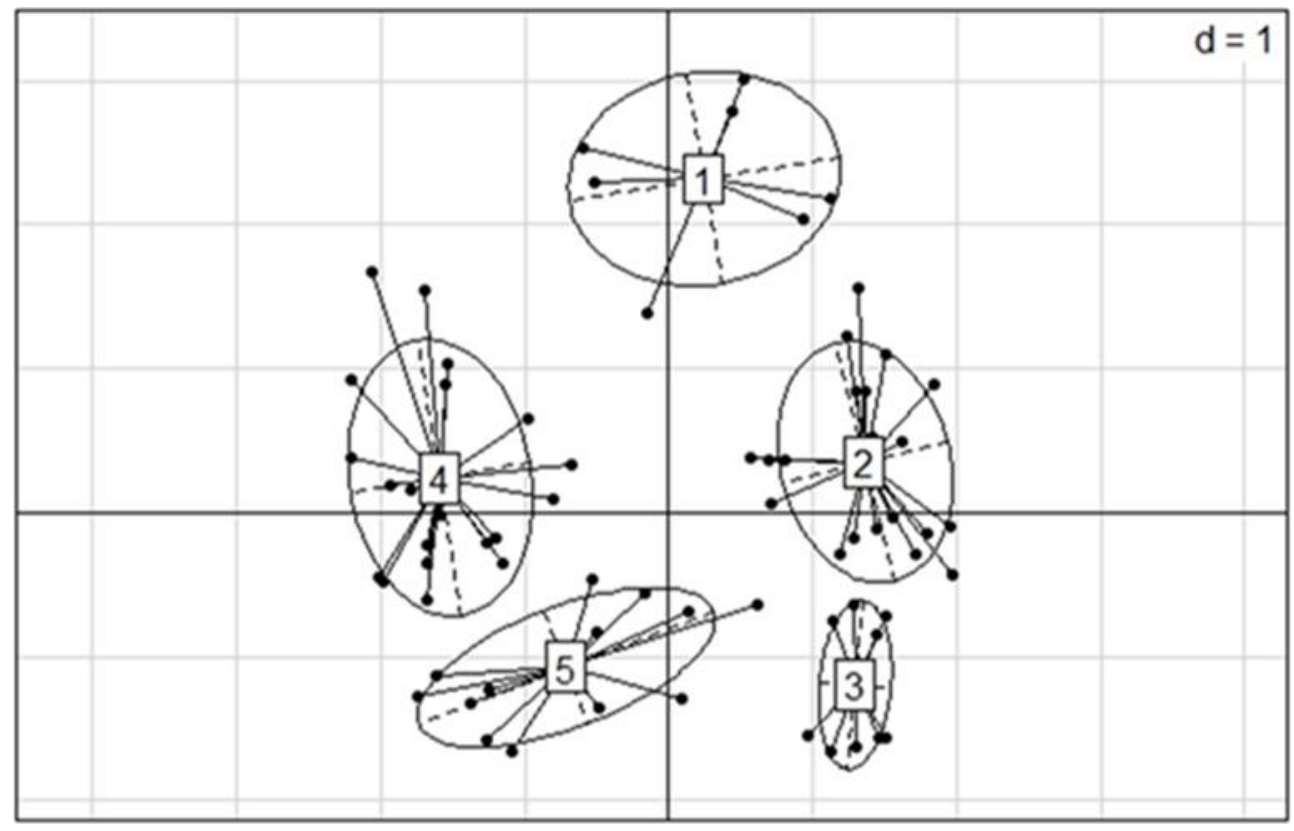

Fig. 2. Projection of clusters on the factorial plan

Large mixed crop-livestock system (group 1) expresses large family size with 40 members, around 22 works in farm ( $50 \%$ male, $50 \%$ female) reflecting work on milking activities and its effects on total net income. Cropping system is represented as $69 \%, 12 \%$, and $15 \%$ for fodder, cereal, and cash crops, respectively. Producers represent around $92-93$ TLU; $50 \%$ as dairy animals and $50 \%$ as fattening with 18 head of small ruminants. Dairy animals are contributed as $62.4 \%$ Buffaloes, 23.8\% Baladi and $13.7 \%$ Crossbred.

Small mixed crop-livestock system (group 2) contributed 2-3 feddan and around 10 TLU. Large ruminants (from 4 to 5 heads) are represented as $50 \%$ Buffaloes, 32\% Baladi and Crossbred. Around $75 \%$ of the total herd structure constituted dairy animals and fattening activities. Cropping systems are mainly represented with two third as fodder crops; the rest of cultivated area is divided for planting cereal and cash crops. Cereal crop is mainly for home consumption, while cash crop is for supplementary monetary income.

Micro mixed crop-livestock system (group 3) describes small producers with 1-2 feddan oriented for fodder crops (around $42 \%$ of the total cultivated area), cereal crop which represents around $22 \%$ of the total cultivated area and $12.2 \%$ planted with cash crops (mainly vegetables). Herd composition is contributed with less than 5-6 TLU and 1-2 dairy animals, one fattening animal (for one year) and one small ruminant for family consumption.

large herder's milk production (group 4) gathers landless producers with 55 TLU. Buffalo represents around $85 \%$ of the total herd composition; the rest is represented by crossbred dairy animals and around nine heads of small ruminants. Large 
ruminants contribute two third as dairy animals and one third as fattening. Around 8-9 members of the family (with an average size 13-14 members) work on livestock activity.

Small herder's milk production (group 5) gathers small family landless systems in urban zone with 16 TLU in average. Herd structure is composed with 5-6 dairy buffalo, three fattening animals (mainly buffalo) and around 2 small ruminants for family consumption.

\section{Feed efficiency}

\subsection{Feed nutrient}

In Table (1), feed prices and Total Digestible Nutrient (TDN), Crude Protein (CP) and Dry Matter (DM) are showed as standard values for each component (Bach, 2012). DM voluntary intake was estimated as $3 \%$ of the live body weight. The average DM, TDN and CP requirement is around 16.5, 7.32 and $1.32 \mathrm{~kg}$ per day, respectively, was calculated according to dry matter content compared to daily standard requirements of a $550 \mathrm{~kg}$ buffalo producing seven $\mathrm{kg}$ of milk per day with a fat ratio $7.2 \%$ (Table 2) (Thomas, 2008).

As Technical efficiency describes the relation between efficiency and resilience, producers try to decrease their dependency towards inputs by reducing the amount of dry matter to produce one $\mathrm{kg}$ of milk (Daburon, 2013). In Table (3), DM efficiency is represented by performing the DM intake regarding average milk production for each studied groups, which may investigate an idea that the small mixed crop-livestock system (group 2) and the micro mixed crop-livestock system (group 3) represented the most efficient feeding systems as valorized feed intake. Buffalo achieved high dry matter efficiency in all studied groups of farming systems in compared with Baladi and crossbred $(2.45,1.91,1.49,1.93$ and $2.28 \mathrm{~kg}$ for group 1, 2, 3,4 and 5 , respectively). Buffalo has longer productive life time than baladi and crossbred cows, with high fat percentage (around 7\%). If its good management, milk production can be reached two to three times higher than that of local breeds. This is in accordance with what mentioned by Daburon (2013) who stated that buffalo have high conversion rate (ability to use fodder and rough) in terms of milk production and fat percentage. Buffalo is particularly adapted to hard condition, was used in cropping activities, but now considered the main traditional dairy breed in most cultivated area in Egypt.
Table 1. Average price of ration components in the markets around the Greater Cairo during the study; $\%$ Total Digestible Nutrient (TDN); \% Crude Protein $(\mathrm{CP})$, and \% Dry Matter (DM)

\begin{tabular}{|c|c|c|c|c|}
\hline Feed type & $\begin{array}{c}\text { Feed } \\
\text { price } \\
(\mathrm{LE} / \mathrm{Kg})\end{array}$ & $\begin{array}{c}\% \\
\text { TDN }\end{array}$ & $\begin{array}{l}\% \\
\mathrm{CP}\end{array}$ & $\begin{array}{c}\% \\
\text { DM }\end{array}$ \\
\hline Barley & 3.5 & 84 & 13 & 88 \\
\hline Beans & 3.7 & 78 & 23 & 88 \\
\hline Berseem & 0.3 & 83 & 20 & 12 \\
\hline Biscuits & 1 & 95 & 10 & 90 \\
\hline Bran & 2 & 71 & 17 & 89 \\
\hline Bread & 1.5 & 89 & 15 & 68 \\
\hline Carottes & 0.4 & 83 & 10 & 12 \\
\hline Cotton seed & 2.5 & 98 & 25 & 90 \\
\hline Darawa & 0.3 & 59 & 12 & 23 \\
\hline $\begin{array}{l}\text { Dora (grain } \\
\text { maize) }\end{array}$ & 2.6 & 89 & 9 & 88 \\
\hline Corn gluten & 2.5 & 82 & 22 & 88 \\
\hline Pellets & 2.3 & 71 & 17 & 89 \\
\hline $\begin{array}{l}\text { Residual } \\
\text { hoven }\end{array}$ & 2.3 & 89 & 10 & 91 \\
\hline Soya bean & 4 & 81 & 40 & 88 \\
\hline Straw (beans) & 1.3 & 65 & 15 & 90 \\
\hline Straw (hegazi) & 1.5 & 46 & 15 & 93 \\
\hline Straw (rice) & 0.9 & 40 & 3 & 93 \\
\hline $\begin{array}{l}\text { Straw (sugar } \\
\text { cane) }\end{array}$ & 0.4 & 25 & 2 & 91 \\
\hline Straw (wheat) & 0.7 & 48 & 5 & 93 \\
\hline Sweet potatoes & 1 & 80 & 10 & 21 \\
\hline Bean peals & 2 & 51 & 15 & 95 \\
\hline
\end{tabular}

Table 2. Daily requirement of dairy large ruminants

\begin{tabular}{|c|c|c|}
\hline $\mathbf{D M}(\mathbf{k g})$ & TDN $(\mathbf{k g})$ & $\mathbf{C P}(\mathbf{k g})$ \\
\hline 16.5 & 7.32 & 1.32 \\
\hline
\end{tabular}


Table 3. Dry matter (DM) efficiency of studied species (buffalo, baladi, and crossbred) for each group

\begin{tabular}{|c|c|c|c|c|c|}
\hline Variable /Group & $\mathbf{1}$ & $\mathbf{2}$ & $\mathbf{3}$ & $\mathbf{4}$ & $\mathbf{5}$ \\
\hline $\begin{array}{c}\text { TDN ratio }(\mathrm{kg}) \\
\text { CP ratio }(\mathrm{kg})\end{array}$ & 1.61 & 1.35 & 1.34 & 1.61 & 1.61 \\
DM ratio $(\mathrm{kg})$ & 1.07 & 0.92 & 0.93 & 1.06 & 1.10 \\
$\begin{array}{c}\text { DM efficiency of } \\
\text { Buffalo }(\mathrm{kg})\end{array}$ & 2.45 & 1.91 & 1.49 & 1.93 & 2.28 \\
$\begin{array}{c}\text { DM efficiency of } \\
\text { Baladi }(\mathrm{kg})\end{array}$ & 1.00 & 0.64 & 0.70 & 0.10 & 0.00 \\
$\begin{array}{c}\text { DM efficiency of } \\
\text { Crossbred }(\mathrm{kg})\end{array}$ & 1.50 & 0.84 & 0.79 & 0.30 & 0.00 \\
\hline
\end{tabular}

\subsection{Feed performance}

Feed cost was calculated due to quantity of fodder and concentrates included in rations. The total feed cost per TLU per day is represented as the highest for land-access producers (groups 1, 2 and 3) compared to landless producers (groups 4 and 5). In consequence, fodder cost per TLU per day and concentrate cost per TLU per day have been reported as highly for land-access producers (groups 1, 2 and 3). Moreover, fodder costs and concentrate costs are more contributed in the total feed costs in land-access production systems (groups 1, 2 and 3). The small and the micro mixed crop-livestock systems (group 2 and group 3) showed the highest total dairy feed cost per litre with a maximum of $5.15 \mathrm{LE}$, meanwhile the lowest dairy feed cost per litre was achieved by the larger herder's milk production (group 4) and the large mixed crop-livestock systems (group 1). Regarding dairy species, landless producers (group 4 and 5) recorded the highest feed cost for buffalo as it contributed the main dairy animal for those production systems. Among land-access producers, the lowest feed cost for dairy species was achieved by the micro mixed crop-Livestock systems (group 3) (around two LE/litre for buffaloes, one LE/litre for baladi and $0.1 \mathrm{LE} /$ litre for crossbred) referring the highest feed efficiency included these production systems (Table 4).
Table 4. Feed costs per TLU for different groups

\begin{tabular}{|c|c|c|c|c|c|}
\hline Variable/ Group & 1 & 2 & 3 & 4 & 5 \\
\hline $\begin{array}{lll}\text { Feed } & \text { cost } & \text { per } \\
\text { TLU } & \text { per } & \text { day } \\
(\text { LE) } & & \end{array}$ & 4470 & 3939 & 3620 & 3325 & 2731 \\
\hline $\begin{array}{l}\text { Fodder cost per } \\
\text { TLU per day } \\
\text { (LE) }\end{array}$ & 515 & 507 & 491 & 376 & 525 \\
\hline $\begin{array}{l}\text { Concentrate cost } \\
\text { per TLU per day } \\
\text { (LE) }\end{array}$ & 1242 & 1552 & 1561 & 1402 & 1475 \\
\hline $\begin{array}{l}\% \text { Fodder cost in } \\
\text { the total feed } \\
\text { cost }\end{array}$ & 19 & 24 & 19 & 0 & 7 \\
\hline $\begin{array}{l}\% \text { Concentrate } \\
\text { cost in the total } \\
\text { feed cost (feed } \\
\text { autonomy) }\end{array}$ & 75 & 80 & 73 & 48 & 58 \\
\hline $\begin{array}{l}\text { Total dairy feed } \\
\text { cost per litre } \\
(\text { LE) }\end{array}$ & 2.40 & 5.15 & 3.75 & 1.66 & 2.97 \\
\hline $\begin{array}{l}\text { Feed cost per } \\
\text { Buffalo per litre } \\
(\text { LE) }\end{array}$ & 2.99 & 2.25 & 1.99 & 3.64 & 3.52 \\
\hline $\begin{array}{l}\text { Feed cost per } \\
\text { Baladi per litre } \\
(\text { LE) }\end{array}$ & 1.39 & 1.15 & 1.06 & 0.22 & 0.00 \\
\hline $\begin{array}{ll}\text { Feed cost } & \text { per } \\
\text { Crossbred } & \text { per } \\
\text { litre (LE) } & \end{array}$ & 1.13 & 0.21 & 0.10 & 1.58 & 0.00 \\
\hline
\end{tabular}

Concentrates represent from $60 \%$ to $80 \%$ of total feed cost (Daburon, 2013). As most producers focus on concentrates when feeding their animals in terms of increasing milk production, the percentage of concentrate in the Total Milk Ration (TMR) is directly linked to the economic feed efficiency as well as resilience ability. The small, micro mixed crop-livestock systems (group 2 and 3), who have the opportunity to produce fodder, achieve high economic efficiency due to their low intensive feed strategy, therefore, the more resilience to the external variation of market price. High production of milk per head per year and per feddan allocated to fodder crops represented by the small and the micro crop-livestock systems (group 
2 and 3) offset the high feed cost to produce one liter of milk. On contrary, landless producers (group 4 and 5) seem to have low economical feeding systems efficiency because of highly exposed to market price both for concentrates and fodder crops. The large mixed crop-livestock systems (group 1) represent an intermediate status that producers cultivate fodders inside farm, but remain low economic efficiency in terms of their intensive feed strategy. The above results are in deal with what was found by Daburon (2013) who reported that small producers are more efficient regarding their feed strategy and less dependency on market price because of the ability to produce fodder inside farm.

Dairy performance was estimated according to milk production per head per year as well as milk production per feddan allocated to fodder crops (Table 5). The large herder's milk production (group 4) was the highest in number of dairy large ruminants and as well as the percentage of dairy buffalo in the total number of dairy large ruminants.
Baladi represented the highest percentage dairy ruminants for the small mixed crop-livestock systems (group 2), where crossbred represented mostly for the micro mixed crop-livestock systems (group 3). The small mixed crop-livestock systems (group 2) recorded the highest milk production per dairy animal per year (1133.40 liter/head/ year). Landless producers (group 4 and 5) recorded 684 and 93 liter per head per year, respectively. The small herder's milk production (group 5) showed the lowest milk production (around 93.72 litre per head per year). The small and the micro mixed crop-livestock farms (group 2 and 3) represented the maximum milk production per feddan allocated to fodder crops (1539.50 and 814.32 liter/feddan, respectively). The lowest milk production per feddan allocated to fodder crops was achieved by the large mixed crop-livestock systems (group 1) (around 85 liter/feddan) and the landless producers (group 4 and 5) were 242.85 and 149.73 liter per feddan, respectively.

Table 5. Least Square Means of dairy performance ( $L S M \pm S E$ ) for different groups

\begin{tabular}{|l|c|c|c|c|c|}
\hline \multicolumn{1}{|c|}{ Variable / Group } & $\mathbf{1}$ & $\mathbf{2}$ & $\mathbf{3}$ & $\mathbf{4}$ & $\mathbf{5}$ \\
\hline $\begin{array}{l}\text { Number of dairy } \\
\text { large ruminants per } \\
\text { farm }\end{array}$ & $20.11 \pm 3.96^{(\mathrm{b})}$ & $2.64 \pm 0.19^{(\mathrm{c})}$ & $5.69 \pm 2.30^{(\mathrm{c})}$ & $74.00 \pm 5.53^{(\mathrm{a})}$ & $6.85 \pm 2.47^{(\mathrm{c})}$ \\
$\begin{array}{l}\text { \% Dairy buffalo per } \\
\text { farm }\end{array}$ & $0.77 \pm 0.10^{(\mathrm{a})}$ & $0.60 \pm 0.07^{(\mathrm{a})}$ & $0.62 \pm 0.06^{(\mathrm{a})}$ & $0.91 \pm 0.06^{(\mathrm{a})}$ & $0.90 \pm 0.15^{(\mathrm{a})}$ \\
$\begin{array}{l}\text { \% Dairy baladi cow } \\
\text { per farm }\end{array}$ & $0.11 \pm 0.09^{(\mathrm{ab})}$ & $0.35 \pm 0.06^{(\mathrm{a})}$ & $0.24 \pm 0.05^{(\mathrm{ab})}$ & $0.15 \pm 0.03^{(\mathrm{b})}$ & $0.05 \pm 0.01^{(\mathrm{b})}$ \\
$\begin{array}{l}\text { \% Dairy crossbred } \\
\text { per farm }\end{array}$ & $0.10 \pm 0.02^{(\mathrm{a})}$ & $0.05 \pm 0.01^{(\mathrm{a})}$ & $0.13 \pm 0.04^{(\mathrm{a})}$ & $0.07 \pm 0.04^{(\mathrm{a})}$ & $0.02 \pm 0.01^{(\mathrm{a})}$ \\
$\begin{array}{l}\text { Total milk production } \\
\text { per dairy animal per } \\
\text { year }\end{array}$ & $273.91 \pm 216.35^{(\mathrm{bc})}$ & $1133.40 \pm 157.41^{(\mathrm{a})}$ & $763.57 \pm 135.33^{(\mathrm{ab})}$ & $684.17 \pm 145.13^{(\mathrm{abc})}$ & $93.72 \pm 13.01^{(\mathrm{c})}$ \\
$\begin{array}{l}\text { Total milk production/ } \\
\text { fodder crops per year }\end{array}$ & $85.24 \pm 11.15^{(\mathrm{b})}$ & $1539.50 \pm 201.50^{(\mathrm{a})}$ & $814.32 \pm 173.24^{(\mathrm{ab})}$ & $242.85 \pm 185.78^{(\mathrm{b})}$ & $149.73 \pm 19.59^{(\mathrm{b})}$ \\
\hline
\end{tabular}

Means in the same row superscribed with different letters are significantly $(P>0.05)$.

Buffalo is the main dairy animal for most producers, given milk-fat percentage which is preferred by consumers. The small and the micro mixed crop-livestock production systems (group 2 and 3 ) are more efficient in their ability to valorize feed, dealt with milk production per head per year and milk production per feddan cultivated with fod- der crops. On opposition, the landless large and small herder's milk producers (group 4 and 5) are focusing on concentrates when feeding in terms of increasing milk production. The large amount of highly energetic feeds (concentrate) lead to a suboptimal valorization of the intake, and chronic acidosis which negatively affect feed efficiency in 
such production systems (Enemark, 2008). Therefore, the landless large and small herder's milk producers (group 4 and 5) having the lowest feed efficiency with low amount of fodder and large amount of concentrates cause a waste of nutrients (animals aren't to maintain dry matter feed intake). It can be concluded that the small, micro mixed crop-livestock systems (group 2 and 3) achieved the highest feed efficiency regarding milk production in Urban and Peri-urban areas which proves the importance of opportunity to cultivate land by fodder crops to feed animals, reflecting increased in technical efficiency for such production systems. Nutrition systems, which applied in these production systems, influence positively economic efficiency, as there is little use of concentrates thus maintaining high productive performance and as well as animal health.

Improving productive performance for small producers in areas around the Greater Cairo can be by creating supposed scenarios or technical packages (the interest in veterinary care and of vaccines to prevent from common diseases and epidemics) using simulation systems. Nongovernmental organizations (NGOs) are recommended as essential in performing efficiency of milk production as milk-sourcing projects are mostly associated with them (Geleti et al 2014). Extension programs can help to support awareness to increase the producer's income throughout assist in dairy marketing operations in order to raise product price to approach good returns and thus increase the Gross Domestic Products (GDP).

\section{REFERENCES}

Abdel-Rahim S.A. 2005. A study on some milk production systems of Egyptian buffalo in Giza governorate. Ph.D. Thesis, Fac. of Agric., Cairo Univ., Egypt, pp. 45-57.

Bach A. 2012. Key indicators for measuring dairy cow performance. Optimization of feed use efficiency in ruminant production systems. In: Bangkok, Thailand, 27 November 2012. Rome, Italy, FAO Animal Production and Health Proceedings. pp. 33-44.
Daburon, A., 2013. Urban and Peri-urban Milk Producers of El Cairo City: an Efficiency Focus. M.Sc. Thesis, Année Universitaire, Motpellier, France. pp. 20-45.

Duncan, D.B. 1955. Multiple Range and Multiple F - Test. Biometrics, 11, 1-42.

Enemark, J. 2008. The monitoring, prevention and treatment of sub-acute ruminal acidosis (SARA). A Review. The Veterinary J., 176(1), 32-43.

Farell, M.J. 1957. The measurement of productive efficiency. J. of the Royal Statistical Society. Series A (General). 120(3), 253-290.

Geleti, D., Hailemaiam, M., Mengistu, A. and Tolera, A. 2014. Analysis of fluid milk value chains at two peri-urban sites in western oromia, Ethiopia: Current Status and Suggestions on how they might evolve. Global Veterinaria 12(1), 104-120.

Goodman, L.A. 1960. Snowball sampling. The Annals of Mathematical Statistics, 32(1), 148-170.

Landais, E. 1996. Typologies d'exploitations agricoles. Nouvelles questions, nouvelles méthodes. Econ. Rurales, 236, 3-15.

Le Moigene, 1977. La Theorie du Systeme general. 2. Udg. 1984. Presses Universitaires du France, $310 \mathrm{p}$.

S.A.S. 2000. SAS users guide Statistical Analysis System Institute, Inc., Cary, NC.

Sere', C. and Steinfeld, H. 1996. World livestock production systems: current status, issues and trends. FAO Animal Production and Health Paper 127, Rome. pp. 223-240.

Smith, J. and Baikey, M. 2006. Urban agriculture and the building of communities. In R. van Veenhuizen. Cities farming for the future: urban agriculture for green and productive cities. RUAF /IDRC/IIRR Paper 89, Leusden. pp. 157-172.

Tabana, A.S. 2000. Development of a decision support sustem for individual dairy farms in mixed irrigated farming systems in the Nile Delta. Ph.D. Thesis, Wageningen Univ., Wageningen, The Netherlands. pp. 34-45.

Thomas, C.S. 2008. Efficient dairy buffalo production. Tumba: Sweden De Laval International AB. 41 p. 